\title{
Degradation of 4-Chlorophenol by Gamma Radiation of ${ }^{137} \mathrm{Cs}$ and X-rays
}

\author{
Julio César González-Juárez, ${ }^{1}$ Jaime Jiménez-Becerril, ${ }^{*, 2}$ and Jesús Cejudo-Álvarez²
}

${ }^{1}$ Instituto Tecnológico de Toluca, Av. Instituto Tecnológico Ex-Rancho la Virgen, Metepec, Estado de México, México 52140. cenuclear@hotmail.com

2 Instituto Nacional de Investigaciones Nucleares. Apartado Postal 18-1027. México, D.F. 11801 México. (+52) 5553297200 ext. 2266. jaime.jimenez@inin.gob.mx

Received November 24, 2009; Accepted May 13, 2010

\begin{abstract}
This paper presents results of radiolytic degradation of 4-chlorophenol in the presence of $\mathrm{TiO}_{2}, \mathrm{Al}_{2} \mathrm{O}_{3}, y \mathrm{SiO}_{2}$, using different radiation sources than ${ }^{60} \mathrm{Co}$, which is so common in this type of experiment. The radiation sources used were X-rays with energy of $100 \mathrm{keV}$ and radiation from ${ }^{137} \mathrm{Cs}(662 \mathrm{keV})$. After irradiation with a dose of 50 cGy X-ray and $\mathrm{TiO}_{2}$ obtained a degradation of about $5 \%$, no degradation was obtained with ${ }^{137} \mathrm{Cs}$ source and other oxides. This may be due to the fact that X-rays have a linear energy transfer (LET) greater value, and in the case of $\mathrm{TiO}_{2}$ present a crystalline structure, whereas the other two oxides are amorphous. Both characteristics result in better formation of a reactive species that allows the degradation of the compound.
\end{abstract}

Keywords: Radiocatalysis, Photocatalysis, Radiation Induced Catalysis, 4-Chlorophenol.

\section{Introduction}

Photocatalysis, an effective method that uses visible and UV radiation and semiconductors, such as $\mathrm{TiO}_{2}$, to treat wastes present in the environment, consists of an advanced oxidation process related to the use of $\bullet \mathrm{OH}$ radical as the main oxidant. Another process, radiocatalysis, is conceptually similar to photocatalysis, in which radicals generated by radiation gamma of ${ }^{60} \mathrm{Co}$ in the presence of oxides such as $\mathrm{TiO}_{2}, \mathrm{Al}_{2} \mathrm{O}_{3}$, and $\mathrm{SiO}_{2}$, allow electronic transferences and generation of reactive species that result in oxidation-reduction of organic compounds. Both are used in the treatment of such organic compounds as dichloromethane, chloroform, phenols, and pesticides [1].

Recent work on radiolysis in heterogeneous systems has been done by Henderson [2], Zacheis et al. [3], Dimitrijevic [4], Milosavljevic and Thomas [5], and Gonzalez and Jiménez [6], all of which propose that radiocatalysis is an extension of photocatalytic processes that occur with visible and UV light. In these, the energy is absorbed by the catalyst (semiconductor) as titanium dioxide, causing the formation of a pair of electron-holes $(\mathrm{e}-/ \mathrm{h}+)$ [7] and the posterior formation of radicals as the ${ }^{\bullet} \mathrm{OH}$. Other authors, such as Follut and Leither [8-9], have concluded that the presence of $\mathrm{TiO}_{2}, \mathrm{Al}_{2} \mathrm{O}_{3}$ during irradiation causes only adsorption effects.

The oxides used in photocatalysis, such as $\mathrm{TiO}_{2}$, require $3.2 \mathrm{eV}$ to produce a pair of charged carriers while $\mathrm{Al}_{2} \mathrm{O}_{3}$ or $\mathrm{SiO}_{2}$ need more than twice that amount of energy [4] to be excited. Thus it is possible that sources such as ${ }^{137} \mathrm{Cs}$, which have energy of $0.662 \mathrm{MeV}$, and X-rays with energy of 100
Resumen. Se presentan los resultados de la degradación de 4-clorofenol por catálisis inducida por radiación ionizante, en el experimento se utilizaron $\mathrm{TiO}_{2}, \mathrm{Al}_{2} \mathrm{O}_{3}$, y $\mathrm{SiO}_{2}$ como catalizadores y radiación gamma de ${ }^{137} \mathrm{Cs}(662 \mathrm{keV})$ además de rayos $\mathrm{X}$ con energía de 100 $\mathrm{keV}$. Después de la irradiación con una dosis de 50 cGy de rayos $\mathrm{X}$ en combinación con $\mathrm{TiO}_{2}$ se obtuvo una degradación de alrededor del $5 \%$, sin embargo no se registró degradación empleando los otros óxidos y la radiación gamma de ${ }^{137} \mathrm{Cs}$, esto puede ser atribuido a que los rayos $\mathrm{X}$ presentan mayores niveles de transferencia lineal de energía mayores que la radiación gamma. Por otro lado, de los tres óxidos empleados, el $\mathrm{TiO}_{2}$ presenta una estructura cristalina, mientras que los otros son amorfos, estas dos características originan una mejor formación de especies reactivas que hacen posible la degradación del compuesto.

Palabras clave: Radiocatálisis, fotocatálisis, catálisis inducida por radiación, 4-clorofenol.

$\mathrm{keV}$, could be used to promote radiocatalysis (Fig. 1).

The use of $\mathrm{X}$-rays in combination with oxides, such as $\mathrm{TiO}_{2}, \mathrm{Al}_{2} \mathrm{O}_{3}$ and $\mathrm{SiO}_{2}$, has not been reported; therefore, this paper aims to demonstrate the feasibility of using radiation sources other than the gamma radiation of the ${ }^{60} \mathrm{Co}$ commonly used in radiocatalysis, and no experiments were performed with another dose.

\section{Results and discussion}

In the gamma and $\mathrm{X}$-ray irradiation for which aluminum and silicium oxides were used as catalysts, no 4-CP degradation was obtained by radiolysis and radiocatalysis; only in using

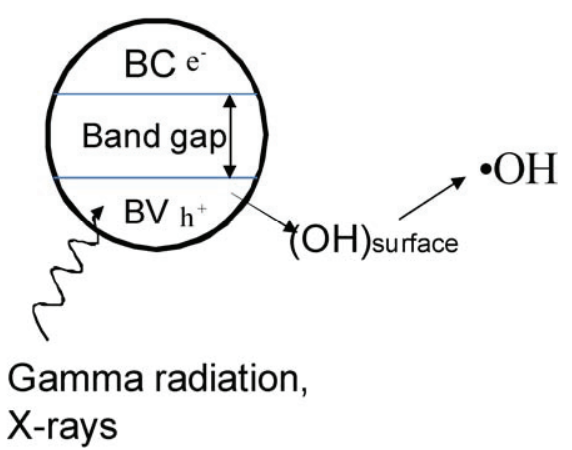

Fig. 1. Excitation of catalyst using gamma radiation and X-rays, this interaction cause the formation a pair of electron-hole and posterior formation of $\bullet \mathrm{OH}$ radicals. 
titanium dioxide and $\mathrm{X}$-rays was 4-CP degradation observed. No evidence of adsorption of 4-CP in the $\mathrm{TiO}_{2}$ was obtained. The results are presented in Table 1 .

The results presented in Table 1 indicate that the dose of $50 \mathrm{cGy}$ of $\mathrm{X}$-rays is not enough to degrade 4-CP by radiolysis; nevertheless, degradation was observed when $\mathrm{TiO} 2$ was used. As the absence of radiolysis was observed in the experiment, the degradation obtained was due only to the interaction of the radiation-oxide.

In previous experiments [6], degradation of 4-CP with ${ }^{60} \mathrm{C} 0$ was observed and was necessary up to $1 \mathrm{kGy}$ to degrade $92 \%$ of a solution of $25 \mathrm{mg} / \mathrm{L}$; therefore, a dose of $1 \mathrm{~Gy}$ is not enough to degrade $9.65 \mathrm{mg} / \mathrm{L}$. That is, in the present experiments, all degradation of 4-CP was a consequence of the catalysis induced by radiation; however, this effect was observed only with $\mathrm{TiO}_{2}$ and $\mathrm{X}$-rays.

The gamma radiation with ${ }^{137} \mathrm{Cs}$ and $\mathrm{X}$-rays had similar interactions with the matter. A Compton scattering predominates in both, since the photoelectric effect occurs between $1 \mathrm{keV}$ and $30 \mathrm{keV}$, and the pair production does not occur at energies less than $1.02 \mathrm{MeV}[10]$.

On the other hand, the radicals and molecular products generated by X-rays $(100 \mathrm{keV})$ and the gamma radiation of ${ }^{137} \mathrm{Cs}(662 \mathrm{keV})$ are different. Yamaguchi [11] calculated the yields of species in water irradiated by monoenergetic photons with energies of $50 \mathrm{eV}-2 \mathrm{MeV}$. Yields of ${ }^{\circ} \mathrm{OH}$ are 2.909 for $100 \mathrm{keV}$ and 3.129 for $662 \mathrm{keV}$ energies, corresponding to $\mathrm{X}$-rays and gamma radiation of ${ }^{137} \mathrm{Cs}$, respectively, in terms of $\mathrm{G}(\mathrm{G}=$ number of molecules of products formed or molecules changed per $100 \mathrm{eV}$ energy absorbed). Stafford et al. (1994) conducted studies of the degradation of 4-chlorophenol with gamma rays and UV radiation, and proposed that degradation of 4-CP is originated mainly by ${ }^{\circ} \mathrm{OH}$ radicals.

As can be seen, for radiation of the ${ }^{137} \mathrm{Cs}(662 \mathrm{keV})$, the generation of ${ }^{\bullet} \mathrm{OH}, \mathrm{H}_{2} \mathrm{O}_{2}$, and $\mathrm{H}_{2}$ is greater than with X-rays; however, the dose used in the present work was not sufficient to induce the radiolytic degradation.

To explain the degradation of 4-CP occurring with X-rays and $\mathrm{TiO}_{2}$, we can consider Linear Energy Transfer (LET). The LET is a measure of the rate of energy deposition and is defined as the linear rate of loss of energy by an ionizing particle traversing a material medium - that is, the amount of energy deposited by ionizing radiation. The LET to ${ }^{60} \mathrm{Co}$ in water is $0.22 \mathrm{keV} / \mu \mathrm{m}^{-1}$; to ${ }^{137} \mathrm{Cs}, 1 \mathrm{keV} / \mu \mathrm{m}^{-1}$; and around $4.7 \mathrm{keV} / \mu \mathrm{m}^{-1}$ for X-rays with $100 \mathrm{keV}$. The suspensions irradiated in these experiments have a density similar to that of water [10].

The LET value is greater for X-rays; therefore, energy deposition is bigger for $\mathrm{X}$-rays than for ${ }^{137} \mathrm{Cs}$ gamma rays.

Table 1. Degradation of 4-CP by radiolysis and radiocatalysis with X-rays irradiation using $\mathrm{TiO}_{2}$ initial concentration $=9.65 \mathrm{mg} / \mathrm{L}$ of 4-CP at dose of $50 \mathrm{cGy}$.

Final Concentration of 4-CP (mg/L)

\begin{tabular}{cc}
\hline Radiolysis & $9.65 \pm 0.1$ \\
Radiocatalysis & $9.21 \pm 0.1$ \\
\hline
\end{tabular}

This fact explains that degradation was obtained only with Xrays. On the other hand, of the three oxides used, the degradation was achieved only with $\mathrm{TiO}_{2}$. This is due to the crystallinity of the catalyst $\left(\mathrm{SiO}_{2}\right.$ and $\mathrm{Al}_{2} \mathrm{O}_{3}$ are amorphous) Rabe et al. [12] observed, that generate pairs of electron-hole augments with the grade of crystallinity of the oxide.

Because of these two factors, the 4-CP degradation was observed only with X-rays and the simultaneous use of $\mathrm{TiO}_{2}$.

\section{Conclusions}

Low doses of gamma radiation of ${ }^{137} \mathrm{Cs}$ and X-rays are not sufficient to degrade 4-CP by radiolysis, even with the addition of $\mathrm{Al}_{2} \mathrm{O}_{3}$ and $\mathrm{SiO}_{2}$. In past experiments with ${ }^{60} \mathrm{Co}$, the necessary doses were on the order of kGy, while the doses used in the present work are on the order of Gy.

Furthermore, $\mathrm{TiO}_{2}$ is the only oxide of the three employed that has a crystalline structure. This feature seems to cause a more efficient energy migration from inside the material to the surface so that the energy promotes a better electron hole pair production and consequently the best generation of the reactive species. In addition, the X-rays deposited greater quantities of energy, compared with ${ }^{137} \mathrm{Cs}$ gamma radiation, which makes possible the degradation of 4-CP using X-rays $(100 \mathrm{keV})$ and $\mathrm{TiO}_{2}$.

\section{Experimental}

\section{Chemicals}

The following chemicals were used as received: $\mathrm{TiO}_{2}, \mathrm{SiO}_{2}$, and $\mathrm{Al}_{2} \mathrm{O}_{3}$ (Degussa Co.); 4-chlorophenol (4-CP), amine-4antipirine, and $\mathrm{Na}-\mathrm{K}$-tartrate (Aldrich); ammonium chloride, potassium ferrocyanide (Baker), and ammonium hydroxide; $\mathrm{NaOH}$ and $\mathrm{HNO}_{3}$ (Merck).

\section{Gamma irradiation and degradation measurement}

Twenty milliliters of 4-CP aqueous solution $(9.65 \mathrm{mg} / \mathrm{L})$ and $20 \mathrm{mg}$ of oxide were mixed to obtain dispersions of $1.0 \mathrm{~g}$ oxide/L of solution. The dispersions obtained were bubbled with $\mathrm{O}_{2}$ for $2 \mathrm{~min}$ at a flow of $120 \mathrm{~cm}^{3} / \mathrm{min}$ and sealed. Sealed vials were gamma irradiated with $1 \mathrm{~Gy}$ in a Gammatron ${ }^{137} \mathrm{Cs}$ irradiator with a dose rate of $165 \mathrm{cGy} / \mathrm{h}$. For the irradiation with X-rays, a W X-ray tube (Philips MCN321) with a focal spot of $8.7 \mathrm{~cm}$ was used, and the vial was placed $100 \mathrm{~cm}$ from the source to provide a dose of $50 \mathrm{cGy}$. The X-ray beam was filtrated with a filter of $\mathrm{Cu}$ of $1.9 \mathrm{~mm}$ and operated at a high voltage of $200 \mathrm{kV}$ and a current of $10 \mathrm{~mA}$ to generate a beam of $100 \mathrm{keV}$.

After irradiation, samples were filtered using $0.4 \mu \mathrm{m}$ Millipore membranes. The 4-CP degradation data were recorded with an UV-Vis Shimadzu 265-FW, and color development was carried out using the amino-4-antipirine method. 


\section{Acknowledgments}

Julio César González thanks the Consejo Nacional de Ciencia y Tecnología (CONACyT) México for scholarship grant no. 181247.

\section{References}

1. Agrios, A. G.; Gray, K. A; Weitz, E. Langmuir 2004, 20, 59115917.

2. Henderson, M. A.; Chambers, S. A.; Daschbach, J. L.; Herman, G. S.; Peden, C. H. F.; Perkins, C. L.; Su, Y.; Wang, Y.; Fryberger, T.; Janata, J. Ionizing radiation induced catalysis on meta oxide particles. U.S. Department of Energy, USA, 1999.

3. Zacheis, G. A.; Gray, K. A.; Kamat, P. V. J. Phys. Chem. B. 1999, 103, 2142-2150.
4. Dimitrijevic, N. M.; Henglein, A.; Meise, L. D. J. Phys. Chem. B. 1999, 103, 7073-7076.

5. Milosavljevic, B. H.; Thomas, J. K. J. Phys. Chem. B. 2003, 107, 11907-11910.

6. González-Juárez, J. C.; Jiménez-Becerril, J. Radiat. Phys. Chem. 2006, 75, 772-768.

7. Blanco, G. J.; Rodríguez, S. M.; Gasca, C. G.; Erick, R.; Bandala, E. R.; Gelover, S.; Leal, T., in: Eliminación de contaminantes por fotocatálisis heterogénea, Blesa, M.A., Editor Comisión Nacional de Energía Atómica, Unidad de Actividad Química: Argentina, 2001, 51-75.

8. Follut, F.; Vel Leitner, N. K. Chemosphere. 2007, 66, 2114-2119.

9. Follut, F.; Vel Leitner, N. K. J. Adv. Ox. Tech. 2007, 10, 121-126.

10. Spinks, J. W.; Woods, R. J. An Introduction to Radiation Chemistry. Ed John Wiley and Sons Inc. 1976

11. Yamaguchi, H. A. Radiat. Phys. Chem. 1989, 34, 801-807.

12. Rabe, J. G.; Allen, A. O. J. Phys. Chem. 1966, 70, 1098-1107. 